\title{
BREAKING THE SILENCE OF THE LAMBS: INTEGRATING MEDICAL STAFF IN PREVENTION OF HUMAN TRAFFICKING
}

\begin{abstract}
Muhtar Cokar ${ }^{1}$, Yesim Isil Ulman², Nadi Bakirci ${ }^{3}$
Abstract: Introduction: Human trafficking, including forced prostitution, is a form of human rights violation regarding right to life and respect for human dignity. The Physician-patient relationship may serve as a process for victim identification on the basis of physicians' responsibilities to detect human trafficking. Method: This empirical study was based on a survey among physicians who may have been in contact with foreign sex workers. Almost eighty physicians in three health facilities were selected according to their high potentiality for coming into contact with foreign sex workers as patients. 228 physicians selected to that aim. 82 of them responded to the questionnaire which was performed in order to evaluate their perception and knowledge human trafficking and their attitudes towards sex work. Results: All physicians think that some women among the sex workers are exploited, exposed to violence and coerced to work against their will (100\%). Almost all of them know that it is compulsory for the healthcare professionals to inform the security forces of the women who are exploited $(80.0 \%)$. Nearly half of them have given medical care to a sex worker $(46.9 \%)$ and 39.0 percent have thought that it may be related to human trafficking. The ones who have informed the police of a human trafficking case are only 10 per cent. Conclusions: We think that the professional should be equipped with ethical values encompassing both a patient's dignity and general welfare. This may include the professional's responsibility to make an assessment as to whether the patient is a victim or a sex worker. Furthermore human trafficking in sex work and sexual health are public health issues therefore it should be covered under standards of practice and ethical codes of conduct.
\end{abstract}

Key words: human dignity, human trafficking, ethics, beneficence, public health, social responsibility

Rompiendo el silencio de los corderos: integrar el personal médico en la prevención de tráfico humano

Resumen: Introducción: El tráfico humano, incluyendo prostitución forzada, es una forma de violación de derechos humanos relacionada con el derecho a la vida y el respeto a la dignidad humana. La relación médico-paciente puede servir como un proceso para identificar víctimas, con base en la responsabilidad del médico de detectar tráfico humano. Método: Este estudio empírico se basó en un cuestionario aplicado a médicos que podían haber estado en contacto con trabajadores sexuales extranjeros. Se seleccionaron unos 80 médicos de tres centros de salud, de acuerdo con su alta probabilidad de entrar en contacto con trabajadores sexuales extranjeros como pacientes. Se seleccionaron 228 médicos para ese objetivo. De estos, 82 respondieron al cuestionario desarrollado para evaluar su percepción y conocimiento del tráfico humano y sus actitudes hacia el trabajo sexual. Resultados: Todos los médicos piensan que algunas mujeres trabajadoras sexuales son explotadas, expuestas a violencia y forzadas a trabajar en contra de su voluntad (100\%). Casi todos saben que es obligatorio para el profesional de la salud el informar a las fuerzas de seguridad sobre las mujeres que son explotadas $(80,0 \%)$. Casi la mitad han proporcionado cuidado médico a un trabajador sexual $(46,9 \%)$ y $39,0 \%$ ha pensado que puede estar relacionado con el tráfico humano. Solo un $10 \%$ ha informado a la policía sobre un caso de tráfico humano. Conclusiones: Pensamos que los profesionales deberían formarse en valores éticos incluyendo tanto la dignidad del paciente como su bienestar general. Esto puede incluir la responsabilidad profesional de evaluar si el paciente es una víctima o un trabajador sexual. Además, el tráfico humano en el trabajo sexual y la salud sexual son temas de salud pública, por lo tanto debieran cubrirse de acuerdo con los estándares de la práctica y códigos éticos de conducta.

Palabras clave: dignidad humana, tráfico humano, ética, beneficencia, salud pública, responsabilidad social

Quebrando o silêncio dos cordeiros: integrando o pessoal médico na prevenção do tráfico de seres humanos

Resumo: Introdução: O tráfico de pessoas, incluindo a prostituição forçada, é uma forma de violação dos direitos humanos sobre o direito à vida e o respeito pela dignidade humana. A relaçáo médico-paciente pode servir como um processo para a identificaçâo das vítimas, com base em responsabilidades dos médicos para detectar o tráfico de seres humanos. Método: Este estudo empírico foi baseado numa pesquisa entre os médicos que possam ter estado em contacto com os trabalhadores do sexo estrangeiros. Quase oitenta médicos em três unidades de saúde foram selecionados de acordo com sua alta potencialidade para entrar em contato com profissionais do sexo estrangeiros como pacientes. 228 médicos foram selecionados para esse objetivo. 82 deles responderam ao questionário que foi realizado com a finalidade de avaliar a sua percepção e o seu conhecimento sobre o tráfico de seres humanos e as suas atitudes em relação ao trabalho sexual. Resultados: Todos os médicos pensam que algumas mulheres entre os trabalhadores do sexo são exploradas, expostas à violência e coagidas a trabalhar contra a sua vontade $(100 \%)$. A maioria deles sabe da obrigação dos profissionais de saúde de informar às forças de segurança sobre mulheres que são exploradas $(80,0 \%)$. Quase metade deles tem dado assistência médica a trabalhadora do sexo $(46,9 \%)$ e 39,0 por cento pensaram que isto pode estar relacionado ao tráfico de seres humanos. Os que informaram à polícia de um caso de tráfico de seres humanos são apenas 10 por cento. Conclusóes: Nós pensamos que o profissional deve estar incorporado de valores éticos que abrangem tanto a dignidade do paciente como o bem-estar geral. Isso deve incluir a responsabilidade do profissional em avaliar se o paciente é uma vítima ou um profissional do sexo. Além disso o tráfico humano no trabalho do sexo e saúde sexual são questôes de saúde pública, por isso, devem ser cobertos pelos padrôes de prática e códigos éticos de conduta.

Palavras-chave: dignidade humana, tráfico de seres humanos, ética, beneficência, saúde pública, responsabilidade social

\footnotetext{
${ }^{1}$ Human Resource Development Foundation, Istanbul, Turkey

${ }^{2}$ Acibadem University School of Medicine, Department of History of Medicine and Ethics, Istanbul, Turkey

Correspondence: yesimul@yahoo.com

${ }^{3}$ Acibadem University School of Medicine, Department of Public Health, Istanbul, Turkey
} 


\section{Introduction $^{4}$}

Human trafficking is one of the most severe forms of human rights violation as regards right to life and respect for human dignity. Human trafficking is a form of exploitation that involves controlling and transporting people through the use of force, deception, or coercion. The end result is that people are moved, often by smuggling or under false pretenses such as tourist visas, from one area or nation into another. The nature of the exploitation is often forced labor for little or no pay in unsafe conditions. Other reasons for trafficking include involuntary prostitution, forced marriage, recruitment of child soldiers, and adoption of babies and children. It is reported to be the third most profitable criminal activity in the world after drug and gun smuggling and has resulted in estimated profits of US\$31 billion in 2008(1).

The trafficking of human beings has attracted considerable public and political concern in recent years. It is commonly understood to involve a variety of crimes and abuses associated with the recruitment, movement and sale of people (including body parts) into a range of exploitative conditions around the world. Media stories of international human trafficking typically conjure up images of all-pervasive organized crime networks, underworld mafias and unscrupulous characters taking advantage of illicit opportunities and the unprecedented ease of communication and transportation offered by the new social and technical infrastructures in an increasingly globalized world. Today human trafficking has become the subject for much empirical research, academic debate and advocacy in diverse disciplines and fields such as criminology, politics, law, human rights, sociologies of migration, gender, and public health. It has been variously understood as the new white slave trade, transnational organized crime, an illegal migration problem, a threat to national sovereignty and security, a labor issue, human rights violations, or a combination

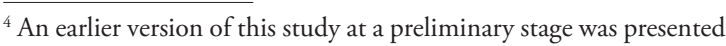
as an oral paper at the European Association of the Centres of Medical Ethics (EACME) Annual Conference, Oslo-Norway, September 6-8, 2010.

This empirical study was started by the approval by the Acibadem University Research Ethics Committee approval code ATADEK 2010-75, on June 6, 2010.
}

of the above. Global and regional responses to the problem have been phenomenal, so much so that concern for trafficking has arguably transformed from 'a poorly funded NGO [non-governmental organization] women's issue in the early 1980's', into 'the global agenda of high politics' of the United States Congress, the European Union (EU), and the United Nations(2).

International human rights standards and conventions prohibit human trafficking (UN Convention on Transnational Organized Crime (2003) UN Protocol to Prevent, Suppress and Punish Trafficking in Persons Especially Women and Children (2000), and Protocol Against Smuggling of Migrants by Land, Sea, and Air (2002). In addition to human trafficking being a violation of international law and human rights norms, it often involves the transportation of persons from one state into another without proper or legal documentation. The success of charging, prosecuting, and punishing offenders involved in human trafficking depends upon intrastate cooperation and mechanisms such as extraterritorial jurisdiction. Currently 32 countries prosecute their nationals for engaging in sex tourism crimes committed abroad. The transnational aspects of this crime make it a unique concern in the field of global justice(3).

Human organs are also abused in trafficking. More than 114,000 organ transplants are performed annually in over 100 countries. Estimating that 5-10\% of kidney transplants result from commercial transactions, WHO has warned against the worldwide "trade for profit in human organs", which tarnishes this life-saving therapy. Although legislation forbidding organ sales exists in most countries, progress has been impeded by weak enforcement and the absence of comprehensive binding international instruments to harmonize regulations and improve cross-national cooperation. The Convention against Trafficking in $\mathrm{Hu}$ man Organs, soon to be adopted by the Council of Europe, provides a solution to these problems by identifying distinct activities that constitute "trafficking in human organs", which ratifying states are obligated to criminalize(4).

As the international awareness of the problem of trafficking in persons has increased, the number 
of studies and publications on the topic has escalated. A substantial number of these publications have set out to describe the various elements associated with human trafficking, including estimates of the scope of the phenomenon, description of trends, and characteristics of victims(5).

The organization of the largest ever EU conference on "Preventing and Combating Trafficking in Human Beings", held in Brussels from 18-20 September 2002, is an example of the growing political priority being accorded to combating human trafficking. The conference, organized by International Organization for Migration (IOM) on behalf of the EU, brought together over 1.000 representatives of European institutions, EU Member States, candidate countries, and relevant third world countries, drawn from governments, international organizations, and NGOs. The conference produced "The Brussels Declaration”, which outlines a set of policy recommendations for the EU in the area of human trafficking. In the United States also, trafficking has been high on the political agenda. In October 2001, the State Department created the Office to Monitor and Combat Trafficking in Persons, and in June 2002, it published a second report assessing the efforts made by 89 countries to combat trafficking in persons. This report is the most comprehensive anti-trafficking review to be issued by any single government $(6)$.

The trafficking of women and girls into forced prostitution and other slavery-like or exploitative conditions is increasingly recognized as one of the world's fastest growing crimes and most significant of human rights violations(7). "The ILO (International Labour Organization) found that almost 2.5 million people who are exploited by private agents and enterprises are in forced labour as a result of human trafficking. This includes not only international cross-border trafficking, but also internal trafficking within a country's own border. Of these 2.5 million, it has been calculated that about 1.1 million are in commercial sexual exploitation (CSE), 800,000 are in other economic exploitation (EE), and 600,000 are undetermined"(8). According to a recent global report on human trafficking, women comprise the vast majority of the detected victims who were trafficked for sexual exploitation. Looking at victims trafficked for forced labour, while men comprise a significant majority, women make up nearly one third of detected victims. In some regions, particularly in Asia, most of the victims of trafficking for forced labour were women(9).

Turkey is mainly a destination country in human trafficking due to its geographical location and higher level of welfare compared to its neighbouring countries. After the collapse of the Soviet system, as a result of unstable economic and social conditions ex-Soviet Union citizens started to search for a way to make their living abroad. A large number of people mobilized seeking job opportunities in and trade with to Turkey including the sex work sector. The informal sex work sector in Turkey was well developed for recruiting those people with low prices and a lack of social support mechanisms $(10,11)$. During the period beginning in 1995, when statistics first began to be kept of the number of persons illegally present in Turkey, to 2007 the total figure was just under 700,000 including the asylum seekers and refugees from Iran, Afghanistan and $\operatorname{Iraq}(12)$. The situation was aggravated by the irregular transit migration of the asylum-seekers(13). Recent turbulent situations due to the wars in Iraq and Syria have increased immigration from the border countries into Turkey.

Turkey signed the "United Nations Convention against Transnational Organized Crime" on December 12, 2000 in Palermo and its additional protocol "Protocol to Prevent, Suppress and Punish Trafficking in Persons Especially Women and Children" in December 13, 2000. Both documents were ratified by the Parliament on January 30, 2003(14). The Council of Europe's Convention on Action against Trafficking in Human Beings, that was ratified by Turkey, as a member country on May 2, 2016, has a comprehensive scope of application, encompassing all forms of trafficking (whether national or transnational, linked or not linked to organised crime) and taking in all persons who are victims of trafficking (women, men or children). The Convention has a human rights perspective and defines trafficking in human beings as a violation of human rights and an offence to the dignity and integrity of the human being(15). 
There has been an organized program to combat human trafficking in Turkey since 2002 with the establishment of the "National Task Force on Fight with Human Trafficking." According to official statistics, 1.120 victims were identified and rescued between 2004 and 2010(16). Statistics also indicated that most identified victims were trafficked for sexual exploitation (87\%) and about $13 \%$ for the purpose of labor exploitation, with a small percentage suffering multiple forms of exploitation. Nearly all of the victims of trafficking were identified by law enforcement officers and there was not a single case identified through health facilities even though foreign sex workers working illegally in Turkey seized in police raids were regularly referred for health checks including compulsory STI screening. It is estimated that there existed a significant number of victims of human trafficking among the foreign sex workers referred for screening which police officers failed to identify. Sex work is regulated by law in Turkey and foreigners are forbidden to work in the sex sector as prostitutes. Each year, within routine law enforcement controls over sex work, thousands of domestic and foreign sex workers are captured and referred for compulsory STI screening. The unique process of physician-patient relationship may serve as a mechanism for victim identification on the basis of physicians' responsibility to detect human trafficking. As gender based violence is recognized as human rights and public health issue(17), we argue that human trafficking in the sex worker field brings about dual responsibility of healthcare provider for protecting patient's health and well-being as well as considering public good in line with ethical conduct.

\section{Method}

\section{Data}

This study attempts to respond to the question: Is there an ethical duty for a professional treating sex workers to notify law enforcement for any suspected human trafficking crime? Although we are aware of the fact that the psycho-social determinants of the sex working area is complicated(18) and the moral values of professionals treating sex workers not easy to investigate and quantify(19), our aim in this study was to raise awareness of the ethical and moral issues of the international com- munity regarding human trafficking.

The study was carried out on the basis of a survey with physicians at three public hospitals in Istanbul during July and August 2010. 228 physicians at three health facilities were selected according to their high potentiality for coming into contact with foreign sex workers. GPs, assistants and specialists at the clinics of internal medicine, surgery, dermatology, gynecology, family medicine and emergency care were included in the study. Eighty two percent of physicians responded to the structured questionnaire which was performed in order to evaluate their perception and knowledge of human trafficking and their attitudes towards sex work.

The hospitals were chosen from the ones where sex workers are likely to consult: Two of them were general hospitals and the third was specific to dermatological and venereal diseases. Only the specialists of internal diseases, dermatology and venereology, obstetrics and gynecology, infectious diseases, surgical diseases, emergency care, family medicine, assistants and GPs were included in the study. The researchers visited the hospitals and spoke with the physicians in charge at the concerned services about the survey. Written informed consent of the participants was obtained by the researchers prior to the study. The number of the doctors to whom the questionnaire was sent was 228. None of the doctors $(n=6)$ from the Hospital of Dermatological and Venereal Diseases answered back. Out of 228 doctors contacted by e-mail, cell phone and site visits, the number of the participants was $82(35 \%)$.

\section{Results}

The questionnaire was composed of two parts. Information on age, sex, branch of specialty, length of experience, type of hospitals (public or private), hospital unit specification (polyclinic, emergency, other) were collected in the first part. The second part consisted of 13 questions based on the Likert scale. It was designed to evaluate the values of the physicians on human trafficking regarding sex work. Five questions in this part aimed to evaluate the attitudes and behavior of the physicians in relation to sex workers with whom they provided medical care. 
Table 1: General characteristics of the study participants.

\begin{tabular}{|l|l|l|l|}
\hline \multirow{2}{*}{ Sex } & & $\begin{array}{l}\text { Number } \\
\text { No 82 }\end{array}$ & $\%$ \\
\hline \multirow{3}{*}{ Speciality } & Female & 45 & 54.9 \\
\cline { 2 - 4 } & Male & 37 & 45.1 \\
\cline { 2 - 4 } & General Practitioner & 9 & 11.0 \\
\cline { 2 - 4 } & Recialist & 47 & 57.3 \\
\hline \multirow{3}{*}{ Instituction } & Public & 26 & 31.7 \\
\cline { 2 - 4 } & Private & 80 & 97.6 \\
\hline \multirow{2}{*}{ Working } & $\begin{array}{l}\text { Inpatient/Outpatient } \\
\text { clinic }\end{array}$ & 2 & 2.4 \\
\hline & & & 80.5 \\
\hline
\end{tabular}

Age mean of all participants was $33.8 \quad(n=82)$. Gender range was almost half and half (female: $54.9 \%, \mathrm{n}=45$ and male: $45.1 \%, \mathrm{n}=37$ ). The physicians had about 10 years of experience on average (9.9 years). The majority of the participants worked at inpatient and outpatient clinics of public hospitals' $(80.5 \%, \mathrm{n}=66)$. Some of them worked at emergency care $(15.9 \%, \mathrm{n}=13)$.

One third of the physicians disagreed that sex work was a job (31.7\%), but they did not think that it should be banned (32.9\%). While another one third agreed with this statement (35.4\%), one fourth thought this job should be banned as it involves violence (24.4\%). $40 \%$ of physicians agreed that the individual's right to self-governance over their body covered sexual intercourse for money as well. Half of the physicians thought that risk of exposure to physical and psychological violence was is higher for sex workers than other women $(56.1 \%)$. Nearly half of the physicians disagreed that sex work was a preferred way of earning a living $(45.7 \%)$, and they disagreed that sex work was is chosen by helpless women who could not find other jobs $(35.4 \%)$ and that sex work was is an easy way of making money $(39.5 \%)$. While one third disagreed sex work was a high-income job (30.5\%), nearly almost half of the participants claimed no opinion (42.7\%).

Table 2: Values of the physicians on human trafficking.

\begin{tabular}{|l|l|l|l|l|l|}
\hline Opinion & $\begin{array}{l}\text { Strongly } \\
\text { Disagree } \\
(\%)\end{array}$ & $\begin{array}{l}\text { Disagree } \\
(\%)\end{array}$ & $\begin{array}{l}\text { No idea } \\
(\%)\end{array}$ & $\begin{array}{l}\text { Agree } \\
\text { Agree } \\
(\%)\end{array}$ \\
\hline $\begin{array}{l}\text { Sex work as providing sexual services in return } \\
\text { for money or goods is a job. }\end{array}$ & 23.2 & 31.7 & 1.2 & 35.4 & 8.5 \\
\hline $\begin{array}{l}\text { Sex work must be banned as it is a way of sexual } \\
\text { violence. }\end{array}$ & 7.3 & 32.9 & 15.9 & 24.4 & 19.5 \\
\hline $\begin{array}{l}\text { Individual's right to self-governance over their } \\
\text { body covers sexual intercourse for money as well. }\end{array}$ & 14.6 & 30.5 & 7.3 & 40.2 & 7.3 \\
\hline $\begin{array}{l}\text { Foreign women should be banned from sex work } \\
\text { in our country. }\end{array}$ & 6.1 & 17.1 & 11.0 & 37.8 & 28.0 \\
\hline $\begin{array}{l}\text { Violence faced by sex workers is a part of their } \\
\text { job. }\end{array}$ & 21.0 & 27.2 & 7.4 & 29.6 & 14.8 \\
\hline $\begin{array}{l}\text { Risk of exposure to physical and psychological } \\
\text { violence is higher for sex workers than other } \\
\text { women. }\end{array}$ & 3.7 & 3.7 & 4.9 & 56.1 & 31.7 \\
\hline Sex workers are coerced to do this job. & 2.5 & 22.5 & 27.5 & 31.3 & 16.3 \\
\hline $\begin{array}{l}\text { Sex work is preferred as it is an easier way of } \\
\text { earning a living. }\end{array}$ & 7.4 & 45.7 & 12.3 & 24.7 & 9.9 \\
\hline $\begin{array}{l}\text { Sex work is chosen by helpless women who } \\
\text { cannot find other jobs. }\end{array}$ & 6.1 & 35.4 & 19.5 & 26.8 & 12.2 \\
\hline Sex workers are compelled to work by deception. & 3.7 & 22.2 & 32.1 & 30.9 & 11.1 \\
\hline Sex working is an easy way of making money. & 14.8 & 6.5 & 9.9 & 28.4 & 7.4 \\
\hline $\begin{array}{l}\text { Most of the income of a sex worker is shared by } \\
\text { others. }\end{array}$ & 6.2 & 15.9 & 30.5 & 29.6 & 37.0 \\
\hline Sex work is a high-income job. & 42.7 & 11.0 & 21.0 \\
\hline
\end{tabular}


Table 3: Attitudes and Behaviors of physicians for sex workers.

\begin{tabular}{|c|c|c|c|}
\hline Opinion & Yes $(\%)$ & $\begin{array}{l}\text { No } \\
(\%)\end{array}$ & No idea (\%) \\
\hline $\begin{array}{l}\text { Do you think that some women among the sex workers are exploited, exposed to } \\
\text { violence and coerced to work against their will? }\end{array}$ & 100.0 & - & - \\
\hline $\begin{array}{l}\text { Is it compulsory for treating healthcare professionals to inform the security forces } \\
\text { of women who are exploited, exposed to violence and coerced to work against } \\
\text { their will? }\end{array}$ & 80.2 & 3.7 & 16.0 \\
\hline $\begin{array}{l}\text { Have you ever, in your professional life, given medical care to any sex worker } \\
\text { including diagnosis, examination and treatment? }\end{array}$ & 46.9 & 53.1 & - \\
\hline $\begin{array}{l}\text { Have you ever thought that one or more of those cases may be related to human } \\
\text { trafficking? }\end{array}$ & 39.0 & 61.0 & - \\
\hline Have you ever informed the police of a human trafficking case? & 10.0 & 90.0 & - \\
\hline
\end{tabular}

All physicians thought that some women among the sex workers were exploited, exposed to violence and coerced to work against their will $(100.0 \%)$. Almost all of them knew that it was is compulsory for the healthcare professionals to inform the security forces of the women who were exploited, exposed to violence and coerced to work against their will (80.0\%). Nearly half of them have given medical care to a sex worker in their professional life including diagnosis, examination and treatment $(46.9 \%)$ and 39.0 percent have suspected that that one or more of those cases may be related to human trafficking. On the other hand, the ones who had informed of a human trafficking case to the police were only 10 percent.

According to our study, agreement or disagreement of healthcare professionals on sex work behavior is heterogeneous. Half of them thought think that sex work was is not a job, while approximately other half believed thinks it was is. The result is half and half for the prohibition of sex working and it is a part of bodily self-governance.

Overall, $60 \%$ of participants $(n=54)$ thought think that foreign women should be banned from sex working. Most of participants thought think that violence and exploitation was is a part of their job. Responders did not think that sex work not an easy way of earning living. They view sex workers as victims. All of the responders think that sex workers are exploited, exposed to violence and coerced to work against their will.

Eighty percent of responders know that it is com- pulsory for the healthcare professionals to inform the security forces of the women who are exploited, exposed to violence and coerced to work against their will. Almost half (\%53.1) of them have given medical care to a sex worker including diagnosis, examination and treatment $(n=43)$. Among those responders only $39.0 \%$ ) have thought that those cases may be related to human trafficking $(n=16)$. Among these sixteen professionals who have given medical care to a sex worker and suspected the case as a victim of human trafficking, only three physicians have reported the case to the police (10\%).

\section{Discussion}

Many people are trafficked for purposes of sexual exploitation; trafficked persons in other types of exploitation may also be sexually abused as a form of coercion and control. As a consequence, trafficked persons, regardless of gender or age, are at risk of developing complications relating to sexual and reproductive health. Addressing sexual and reproductive health issues is therefore an important component of caring for someone who has been trafficked. Sexual abuse can be very stigmatizing for the victim. Health care providers must be supportive of all persons who have experienced such abuse. Even when health care providers offer explanations about medically necessary tests and treatments, trafficked persons may or may not choose to comply with recommended tests and treatments related to their sexual and reproductive health. It can be an empowering experience for people who have been trafficked. It is recognized that there is a tension between 
immediate benefit to the patient of a particular intervention and the long-term benefit of the patient's autonomy and empowerment. Communicating clearly and sensitively with the patient is important because of the intimate nature of sexual and reproductive health examinations and care. The medical examination should be conducted only with the patient's consent and it should be carried out in a compassionate, confidential way(20). Medical problems and procedures in line with a 20 patient-centered care, and information of the potential benefits of all procedures and tests as well as their possible complications available should be told to patients in a manner that is both clear and respectful. While explaining to patients about potential complications; it is advised to be cognizant that the patient might be trafficked. Therefore, informing patients of their legal rights, could be crucial for this vulnerable group to find a way out, if they so desire. Patients should be reassured that they have the right to refuse any aspect of medical examination, and the information would only be released to the authorities with their consent. To pursue good medical practice by protecting patient confidentiality is an important part of the informed consent procedure. However, healthcare professionals should also be forthright with their patients and reveal that results must or may be reported in compliance with legal obligations. It is advised that keeping a careful written record of all findings of the medical examination of all cases of sexual violence is equally vital not only to a patient's care but also to any subsequent legal investigation. The medical chart may become part of the legal record and submitted as evidence in a court case(20). The unique, professional nature of the physicianpatient relationship may provide the victim and authorities crucial evidence in a legal forum to support a way out of trafficking.

Trafficked persons may have health problems that are minor or severe, but few individuals are unscathed. Many will experience injuries and illnesses that are severe, debilitating and often enduring. Abuse, deprivation and stress-filled or terrifying circumstances are all hallmarks of human trafficking(21). Influences on a patient's health may include pre-existing chronic or genetic conditions, exposure to infectious diseases, repetiti- ve physical, sexual and psychological violence, chronic deprivation, hazards related to various forms of labour exploitation, and deterioration of conditions resulting from lack of diagnosis and care (20). As is the case with victims of torture, individuals who have been trafficked are likely to sustain multiple physical or psychological injuries and illnesses and report a complex set of symptoms (21).

A trafficked person may be referred to a health care provider; a patient may disclose a trafficking experience; or a provider may detect signs that suggest an individual has been trafficked. The informed and attentive health care provider can play an important role in assisting and treating individuals who may have suffered unspeakable and repeated abuse. In fact, health care is a central form of prevention and support in the network of anti-trafficking assistance measures. Victims of trafficking, like victims of other forms of abuse, sustain injuries and illnesses that frequently fall to the health sector to address in a safe and confidential way. For a trafficked person, contact with someone in the health sector may be the first - or only- opportunity to explain what has happened or ask for help. Therefore the (good, bad, or indifferent) perception of the healthcare professional towards sex workers is important in this context.

Interestingly enough it is explicit from the records of the Ministry of Internal Affairs that there is no case of human trafficking reported from the medical facilities. Although we have not traced every report to authorities, it is very likely that the three reported cases that we discovered might have already been identified as ordinary victims or the police might have not taken the denunciation as serious.

\section{Sex Work and Values}

The ethical values regarding sex work seem to have stemmed from two contradictory philosophical views. The first of these views admits that sex work is a type of violence against women and emphasizes that prostitution is a sort of exploitation by its nature at the same time(22). As to the second view, sex work is a service exchange and an occupation between consenting individuals. One 
of the reasons of that polarization in the philosophical field is that the prostitution sector includes several various experiences and that the produced values by the parties observing these experiences show differences from each other. Another reason for the polarization is that the phenomenon of prostitution is evaluated from different windows and that some of the elements which create the action are scrutinized more intensely. The values of approval, violence and exploitation, are the ones that determine philosophical polarization(22).

One of two people who perceive that action within the scope of prostitution and has different values for sex work as a type of violence, while the other may argue that the action is an ordinary occupation. Similarly, a person who does prostitution may be perceived either as a victim or a worker by two different people with different values(22). If it is necessary to find a common point, sex workers can be rated and classified according to their exploitation, violence experiences and working conditions. When a scale is created to rate sex workers which are "sexual violence victims" who face the hardest violence and exploitation on the one end; and a "sex worker" who has not faced any violence and earn her/his money in this sector by consent on the other end, we can argue that all sex workers can be rated among these both ends. In other words, it is not possible to reach an exact "victim" or "sex worker" definition and perception in the prostitution sector. It is not hard to say that all sex workers are human beings who are close to being defined as a "sex worker" or a "victim" regarding these three values and features above or under certain degrees(22).

\section{Clinical setting and victim identification}

Medical staff may have come into contact with sex workers during their daily professional routine, they may have participated in moral discussions on sexuality or at the least we can assume that all of them were aware of the news in the media focusing on sex work. Due to the dual nature of sex work regarding values, medical staff experience with sex workers either intellectually or materially may have also resulted in conflicting values. Values are important to make decisions and in conflicting cases ethical decision making is problematical. Although the participants had enough insight to accept the sex workers as victims in our study population, they also had other values like accepting violence as a part of their job, sex work as an easy way to earn a living, and most importantly, the majority of physicians agreed on expelling foreign sex workers from the community (75.8\% including no idea). The issue of accepting individuals as "foreign" and "other" is a matter of human dignity and it may result that we have no obligations for the "other" in a community. We can argue that even the physicians, who are aware of the fact that the sex workers who have been provided healthcare are victims, and should have been reported to the police, have conflicting values towards sex workers. These conflicting values are likely to prevent them from making ethical decision. A lay medical staff is not expected to investigate the nature of sex work as a whole or to be aware of all the details of sexual ethics but they should have a clear idea on reporting criminal cases to security forces on the basis of their duties and responsibilities towards patients and society regarding human rights and human dignity. Inspiring from Wikler's argument on "personal and social responsibility for health" and human suffering(23), we suggest that this duty of the physician should be deliberated within good medical practice and ethics of public health based on human rights law.

\section{Conclusions}

Despite of all its restrictions and its lack of overall sampling representation, this empirical study was based on a survey among physicians who may have been in contact with foreign sex workers, and aims at detecting physicians' perception, and knowledge on human trafficking and their attitudes towards prostitution. The referrals for STI screening can be an important access point for victim identification and for providing knowledge on human trafficking for health care professionals who may help to contribute to human trafficking prevention efforts.

It is observed that the conflict of values was dominant among the responders concerning the values and attitudes on sex workers. They displayed conflicting and intricate values towards sex workers, and therefore they experienced difficulty in identifying them whether as a victim of human 
trafficking forced for sex work, or as a consenting adult performing sex work. More importantly, as some of the respondents have made medical decisions about agents in sex work, they should be aware of the facts in this sector, and they should also have consolidated their values in respect of making ethical decisions. For discerning whether the patient is a victim or an ordinary sex worker, the professional should be equipped with ethical values both respecting patient's dignity, integrity, and fulfilling their legal duties and responsibilities on behalf of patient's well-being.

The physician-patient relationship and medical examination and screening procedure may be helpful for physicians to discern victimization from bodily self-governing choice of prostitution, if they have been informed of the facts of sex work, if their values for sex work have been consolidated on the realities of sex work. In this way there may exist a reasonable imperative to inform or to support the victim. Otherwise the victims may be discriminated or disvalued. The healthcare professional may evaluate this opportunity for reporting the victim in order to lend a hand leading a way out of human trafficking. This ethical attitude can also be justified for the benefit of the patient, the respect to human dignity, human rights and fundamental freedoms(24). These values and norms are in compliance with almost all of the principles of the Declaration of Bioethics and Human Rights (2005) which integrates universal value of human dignity with respect to human life as the core bioethical norm(25) within the global framework of human rights(26). Underlying ethical values of professionalism, obtaining appropriate informed consent(27), respecting patient's right to health, building a compassionate, thoughtful and trustworthy communication with probity, respecting patient confidentiality may help to pave the way for the trafficked victim to get out of that impasse. Furthermore, it is the doctor's legal duty in Turkey to report human trafficking cases to legal authorities(28), which is factually in compliance with the patient's well-being.

Human trafficking is a crucial human rights violation and all of us are responsible for the elimination of it from society. Medical staff also have an additional duty to deal with the health risks of this crime. As the medical examination of a victim may be the only chance for trafficked person to be rescued, health professionals have to be aware of the facts and should have clear values on sexuality, sex work and organized crime. This important human rights disaster should also be included in medical curricula of higher education, should be addressed by conferences and in-service trainings so as to raise awareness as regards ethical values and social responsibility of the healthcare professional. In fact, combating human trafficking and provision of healthcare for sex worker victims of human trafficking are also public health issues, therefore good medical practice and ethical conduct of physicians with social responsibility will serve both human welfare and social utility.

\section{Acknowledgement}

The authors would like to thank immensely Mr. Patrick Owen, J.D., for his critical and analytical revision of our manuscript.

\section{References}

1. Kenedi CA. Trafficking. In: Sajatovic M, Loue S, (editors) Encyclopedia of Immigrant Health. New York: Springer; 2015: 1430-1433. Available from: URL: http://www.springerreference.com/docs/html/chapterdbid/328721.html DOI 10.1007/978-1-4419-5659-0_769. Accessed 01 April 2015.

2. Lee M. Introduction: Understanding Human Trafficking, In: Lee M. (editor) Human Trafficking. Willan Publishing; 2007: 1-91.

3. Sieger LE. Human Trafficking. In: Chatterjee DK. (editor) Encyclopedia of Global Justice; 2011: 508-509 DOI: 10.1007/978-1-4020-9160-5_616. Available from: URL:http://www.springerreference.com/docs/html/chapterdbid/327934.html Accessed: 17.03.2015.

4. López-Fraga M, Domínguez-Gil B, Capron AM, Van Assche K, Martin D, Cozzi E, Delmonico FL, European Committee on Organ Transplantation, European Directorate for the Quality of Medicines \& HealthCare, Council of Europe. A needed Convention against trafficking in human organs. The Lancet 2014; 383(28): 2187-2188.

5. Tyldum G, Brunovskis A. Describing the Unobserved: Methodological Challenges in Empirical Studies on Human Trafficking. International Migration 2005; 43: 17-34. 
Integrating medical staff in prevention of human trafficking - Mubtar Cokar, Yesim Isil Ulman, Nadi Bakirci

6. Laczko F, Gramegna MA. Developing Better Indicators of Human Trafficking. The Brown J. World Aff 2003; X(1):179194.

7. Feinberg DA. Human Trafficking. Foreign Policy Sep. - Oct. 2005; 150: 26.

8. Belser P. Forced Labour and Human Trafficking: Estimating the Profits. International Labour Organization Special Action Programme to Combat Forced Labour, Declaration/WP/42/2005, March 2005: 5. Available from: URL: http://www. ilo.org/wcmsp5/groups/public/@ed_norm/@declaration/documents/publication/wcms_081971.pdf (Accessed August 30, 2015).

9. Chuang JA. Rescuing Trafficking from Ideological Capture: Prostitution Reform and Anti-Trafficking. Law and Policy. University of Pennsylvania Law Review 2010; 158: 1-74.

10. Kirisci K. Managing irregular migration in Turkey: A Political-Bureaucratic Perspective. (CARIM)-AS /61: Robert Schuman Centre for Advance Studies: San Domenico di Fiesole: European University Institute; 2008: 1-25.

11. Icduygu A, Yukseker D. Rethinking Transit Migration in Turkey: Reality and Re-presentation in the Creation of a Migratory Phenomenon. Population, Space and Place 2010; 18(4): 441-456.

12. Turkish Republic, Ministry of Internal Affairs, Immigration General Directorate. Struggle against Human Trafficking: Questions and Answers. Available from: URL: http://www.goc.gov.tr/files/files/insanticaretisss.pdf Accessed 05 April 2015.

13. Council of Europe. Convention on Action against Trafficking in Human Beings. CETS No 197. Available from: URL: http://conventions.coe.int/Treaty/Commun/ChercheSig.asp?NT=197\&CM=\&DF=\&CL=ENG. Accessed 05 April 2015.

14. International Organization for Migration (IOM). 2010. Statistics of Trafficking Cases 01 January - 31 December 2010. IOM Turkey: Available from URL: http://www.countertrafficking.org/2010.html Accessed 13 November 2014

15. O'Connell Davidson J. Will the real sex slave, please stand up. Feminist Review 2006; 83(1): 4-22.

16. Chang G, Kim K. Reconceptualizing Approaches to Human Trafficking: New Directions and Perspectives from the Field(s). Stanford Journal of Civil Rights and Civil Liberties 2007; 3(2): 1-28.

17. Breaking free from gender-based violence. In: Global Health Watch 4, an Alternative World Health Report 2014: 213-219.

18. Zimmerman C. Caring for Trafficked Persons, Guidance for Health Provider's. The International Organization for Migration Action Sheet 2009; 13:149-153.

19. Zimmerman C, et al. 'The Health Risks and Consequences of Trafficking in Women and Adolescents' in Findings from a European study. London School of Hygiene and Tropical Medicine 2003; 20-56.

20. Zimmerman C, Borland R, (eds.) Caring for Trafficked Persons, Guidance for Health Providers. International Organization for Migration (IOM) 2009: 2.

21. Cokar M. Prostitution and Legal Regulations. In: Ordek K, (editors). Sex Workers' Rights are Human Rights. 2011: 101103.

22. Cokar M. Diverse Legal Regulations, In: Cokar M, Kayar HY, (editors). Sex Workers and Laws. 2011: 105-107.

23. Wikler D. Personal and Social Responsibility for Health. In: Anand S, Peter F, Sen A, (editors). Public Health Er-thics, and Equity. Oxford University Press; 2009: 109-134.

24. Andorno R. Human Dignity and Human Rights, In: Have HT, Gordijn B, (editors). Handbook of Global Bioethics. 2014: 45-57.

25. Rawlinson M, Donchin A. The Quest for Universality: Reflections on the Universal Draft Declaration on Bioethics and Human Rights. Developing World Bioethics 2005; 5(3): 258-266.

26. Andorno R. Global bioethics at UNESCO: in defence of the Universal Declaration on Bioethics and Human Rights. $J$ Med Ethics 2007; 33:150-154.

27. Cwikel J, Hoban E. Contentious Issues in Research on Trafficked Women Working in the Sex Industry: Study Design, Ethics, and Methodology. The Journal of Sex Research 2006; 42(4): 306-316.

28. Dundar T, Ozer E, (editors). Welcome to Turkey, Human Trafficking in Turkey. Istanbul: The Human Resource Foundation; 2012.

Received: February 10, 2016

Accepted: April 1, 2016 